
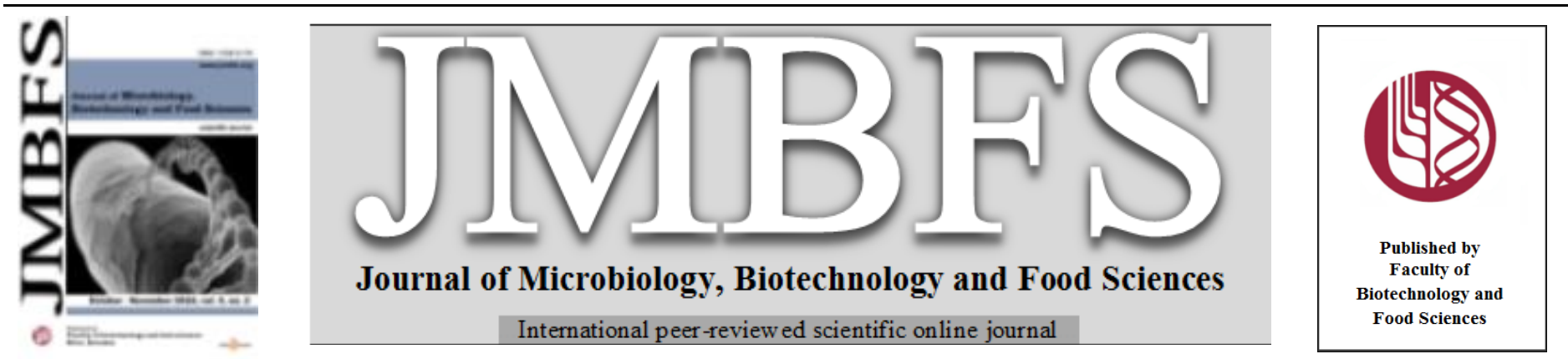

\title{
METHOD FOR DETERMINING FRUIT HARVESTING MATURITY
}

\section{Marcin Bajcar, Bogdan Saletnik, Miłosz Zardzewiały, Barbara Drygaś, Maria Czernicka, Czesław Puchalski, Grzegorz Zaguła*}

Address(es):

University of Rzeszow, Faculty of Biology and Agriculture, Department of Bioenergy Technologies, 4 Zelwerowicza St, $35-601$ Rzeszow, Poland, (17) 785 50 46.

*Corresponding author: g_zagula@univ.rzeszow.pl

doi: 10.15414/jmbfs.2016.6.2.773-776

\section{ARTICLE INFO}

Received 5. 10. 2015

Revised 17. 2. 2016

Accepted 9. 5. 2016

Published 3. 10. 2016

Regular article

open $\partial_{\text {access }}$

\begin{abstract}
Accurate identification of fruit harvest timing is quite a complicated issue. We know several methods of determining harvest maturity in climacteric fruits; these include measurement of: firmness, total solids contents, respiration rate, ethylene emission measurement as well starch tests. On the other hand non-climacteric fruits (no collective maturity phase) are identified as suitable for harvesting by evaluating their colour. The first three aforementioned basic methods can be combined into a single tool, the so-called Streiff index. All the characteristics identified herein, i.e.: starch assay, total solids (including sugars, tannins, vitamins, organic acids, etc.), as well as firmness, corresponding to protopectin-pectin conversion, produce caloric response. Hence, the correlation between fruit maturity and the caloric response of the material provides the basis for an innovative test enabling assessment of harvest maturity in fruit. Caloric response is largely impacted by the changing structure of fruit dry mass. The calorific content of fruit during maturation process decreases due to the conversion of the water-insoluble starch, with a calorific value of $4200 \mathrm{cal} / \mathrm{g}$, into soluble monosaccharides 3750 $\mathrm{cal} / \mathrm{g}$. The study presents a novel calorimetric method of assessing harvest maturity in fruit and the presentation is based on fruit of selected varieties of apples, tomatoes and strawberries. The calorimetric maturity thresholds have been determined for these fruits at the following levels: apples $-3930 \mathrm{cal} / \mathrm{g} \mathrm{s.m.,} \mathrm{strawberries}-3880 \mathrm{cal} / \mathrm{g} \mathrm{s.m}$. and tomatoes $-3910 \mathrm{cal} / \mathrm{g}$.
\end{abstract}

Keywords: fruits, harvesting maturity, calorific value

\section{INTRODUCTION}

The timing of fruit picking (harvest maturity) significantly impacts the duration of storage and quality parameters at the time of commercial operations. To make sure fruit maintain good quality and stability in storage, they should be collected at the most accurately defined time (Blaszczyk, 2006). This is also one of those factors which can be controlled with precision (Tomala, 2002). In order to determine harvest maturity in apples it is necessary to use assessment methods which enable precise evaluation of their condition. Generally these methods are not readily available for fruit farmers since they involve use of costly equipment (e.g. the procedure of measuring ethylene concentration in apple core). Others require a few measurements to be performed simultaneously, e.g. concentrations of ethylene, total solids and fruit firmness (Lysiak, 1998). In recent years there have been attempts to use ultrasound waves in evaluating fruit ripeness and in accessing colour changes during the process of ripening (Mizrach $\boldsymbol{e t}$ al. 2000). Yet, the methods are still not recognized as fully legitimate and reliable in this type of measurements.

Harvest maturity in fruit designated for long-term storage (6-8 months) can be most effectively determined by measuring concentration of ethylene in the fruit core (Tomala, 1995). The procedure requires the use of gas chromatograph, available at specialist laboratories. Harvest time can also be predicted with the use of induced ethylene method or by determining Streif index. As reported by previous studies, at harvest Streif index should be in the range 0.9-1.1 and it should not be lower than 0.8. Many years of observations suggest that during a normal period of ripening the time needed for a change in the index from 0.9 to 0.8 is usually approx. 7 days. Even though they are accurate, these methods require costly measuring instruments (Lysiak 1998).

The easily available, affordable and simple methods include the test for starch. It involves observation of starch decomposition which occurs during the maturation process in apple fruit. Research examining this phenomenon showed close relationship between proportional content of starch and the degree of fruit maturity. Special model charts, which have been developed, are by convention applied to determine the so-called starch index, a function of starch content in a fruit at the cross-section perpendicular to its centre line (Tomala 1995). Dark blue complexes, which emerge as a result of reaction between iodine and starch, represent areas occupied by starch; these are subsequently compared with model photographs and rated on a scale from 1 to 10 . It is difficult to explicitly identify the area occupied by starch (the value of starch index SI results from it) due to the varied starch patterns encountered in different varieties. Precision of the assay also depends on the quality of lighting applied to the examined area of the sample, as well as individual subjective perception of the person performing the test (Peirs et al., 2002). Application of this simplified assay procedure leads to numerous errors. Hence, it is necessary to improve accuracy and reliability of measurements by using enhanced methods of reading and calculating the value of starch index. Other well-known and commonly applied methods include examination of the fruit flesh with a manual firmness tester and determination of refractive index of the total solids (Zagula et al., 2013).

Less frequently applied methods include the procedure of examining the image during starch decomposition with the use of three computerized video devices (Domagala et al., 2007). Another method applies a combined system of colour video camera and spectrophotometer to forecast the level of sugar contents in fruits, which is a critical parameter for the level of fruit maturity. The authors suggest the two methods could be combined into one joint algorithm. The entire procedure is highly effective and time-efficient - one measurement takes only 3.5 seconds (Steinmetz et al., 1999). Finally, the question of expanding the visual system to include bicolour fruit - measurement of colour progression in multicolour fruit is very important, yet highly complicated given the typically available and insufficiently accurate measurement instruments such as calorimeters and chronometers. The proposed system enables observation of a wider spectrum of the colour progression in a multi-colour fruit during the entire maturation process, and consequently its classification in terms of ripeness level (Kang et al., 2008). There are also methods which correlate the degree of fruit maturity with their sliding force and friction force (Puchalski, 2001).

The aim of the study was to find the individual method to indicate the optimum date of harvesting time for selected groups of fruit on the basis of physicochemical and mechanical properties.

\section{MATERIALS AND METHODS}

The material selected for the study comprised three species of fruit, most popular in the Central European market, These were represented by 'Jonagold' apples, 'Elkat' strawberries and 'Bonaparte' tomatoes. Typical harvesting times, as well 
as parametres for determining harvest maturity in these fruit varieties are shown in Table 1.

\begin{tabular}{lccccc}
\multicolumn{6}{c}{ Table 1 Harvest maturity time and basic parameters identifying harvest maturity in fruit (Pieniażek, 1995) } \\
\hline Variety (species) & $\begin{array}{c}\text { Harvest } \\
\text { maturity } \\
\text { timing }\end{array}$ & $\begin{array}{c}\text { Total solids } \\
\text { content, } \%\end{array}$ & Firmness, N & Starch index & Fruit colour \\
\hline Jonagold (apple) & $20.09-10.10$ & $11.5-12$ & $72-78$ & $5-7$ & - \\
\hline Elkat (strawberry) & $10-30.06$ & $7.5-8$ & - & - & $\begin{array}{c}\text { Entire fruit has } \\
\text { reached the target } \\
\text { colour }\end{array}$ \\
\hline Bonaparte (tomato) & $\begin{array}{c}\text { Cyclic } \\
\text { cultivation } \\
\text { indoors } \\
\text { (greenhouse) }\end{array}$ & $5.3-6$ & $14-15$ & - & $\begin{array}{c}2 / 3 \text { of the fruit } \\
\text { has reached the } \\
\text { target colour }\end{array}$ \\
\hline
\end{tabular}

Potential harvest maturity timing was taken into account in determining the initial stage of the observation and the timeframes of the assessment were defined for the specific fruits in the way shown in Table 2.

Table 2 Dates of fruit picking or assessment (in 16 repetitions).

\begin{tabular}{lccc}
\hline \multirow{2}{*}{ Object of study } & \multicolumn{3}{c}{ Date of assessment } \\
\cline { 2 - 4 } & 1 & 2 & 3 \\
\hline Jonagold (apple) & 20.07 .2014 & 01.09 .2014 & 10.10 .2014 \\
\hline Elkat (strawberry) & 20.05 .2014 & 10.06 .2014 & 30.06 .2014 \\
\hline $\begin{array}{l}\text { Bonaparte } \\
\text { tomato) }\end{array}$ & 20.05 .2014 & 10.06 .2014 & 30.06 .2014
\end{tabular}

In accordance with the design, samples were collected three times during the process of fruit maturation, starting at the early stage after the green fruit has been formed and ending at the time of the potential harvest maturity. Each time analytical tests were carried out in 16 fruits of each variety, in accordance with Student's t-test identifying the significant number of repetitions in one group of fruit:

$$
r \geq 2 \cdot\left[\frac{t_{\alpha} \cdot V}{d}\right]^{2},
$$

where:

$\mathrm{r}$ - explored number of repetitions

- Student's t-value at the significance level $\mathrm{p}=0.95$, equals 2,030

$\mathrm{d}[\%]$ - assessment precision reflected by the standard deviation in measurement results acquired in a series of repetitions of the same material - equal $2 \%$;
$\mathrm{V}[\%]$ - value of variability index for 35 pieces of fruit in a test sample - equal $2.7 \%$.

The analytical tests conducted at each stage were designed to identify the level of fruit maturity based the following factors:

- contents of water, ash and volatile substances measured with the use of TGA 701 thermogravimetric analyser LECO, in compliance with standards: (PN90/A-75101:2003); (PN-EN 1135:2002); (PN-C-04708-3: 1997).

- calorific value of dry matter with the use of AC 500 bomb calorimeter LECO, according to standard: PN-EN 14918:2010(U)

- the value of total soluble solids, identified by means of ATAGO refractometer (PN-90/A-75101:2002)

To achieve this the homogenized raw material was subjected to drying in a laboratory dryer, at the temperature of $105^{\circ} \mathrm{C}$, and then refined in a ball grinder and pelleted by means of Laormann apparatus. Calorific value was determined by incinerating the sample in oxygen atmosphere, in bomb calorimeter placed in water.

Statistical analyses of the obtained results were conducted by means of Statgraphics 4.1 Plus. Mean values were compared using Student's t-test and Duncan's test at the level of significance $\mathrm{p}=0.05$ for $\mathrm{n}=16$.

\section{RESULTS AND DISCUSSION}

Correlation tables were generated for the consecutive samples, to present the assessed analytical parameters (Tables 3-5).

Table 3 Results of analytical tests, with standard deviations, for the consecutive assessments of Jonagold apple variety

\begin{tabular}{lcccc}
\hline Date of test & Total solids, $\%$ & $\begin{array}{c}\text { Content of } \\
\text { water, } \%\end{array}$ & $\begin{array}{c}\text { Content of ash, } \\
\%\end{array}$ & $\begin{array}{c}\text { Content of } \\
\text { volatile } \\
\text { substances, } \%\end{array}$ \\
\hline 20.07 .2014 & $8.57^{\mathrm{a}} \pm 0.04$ & $82.45^{\mathrm{a}} \pm 0.19$ & $0.53^{\mathrm{b}} \pm 0.07$ & $0.73^{\mathrm{a}} \pm 0.15$ \\
\hline 01.09 .2014 & $9.80^{\mathrm{b}} \pm 0.13$ & $82.71^{\mathrm{a}} \pm 0.14$ & $0.44^{\mathrm{b}} \pm 0.05$ & $1.23^{\mathrm{b}} \pm 0.08$ \\
\hline 10.10 .2014 & $11.50^{\mathrm{c}} \pm 0.07$ & $82.67^{\mathrm{a}} \pm 0.10$ & $0.26^{\mathrm{a}} \pm 0.01$ & $3.81^{\mathrm{c}} \pm 0.38$ \\
\hline Legend: the same letters (for each parameter) show there are no statistically significant differences at $p=0.05$
\end{tabular}

In course of fruit and vegetable ripening, the quantity of monosaccharides in cell sap increases; these dissolve in water contributing to increased total soluble solids (Dominguez et al., 2012). Statistically significant changes were observed in the value of total solids in Jonagold apple variety. During the maturation process the value of this parameter increased by nearly $3 \%$, which is linked with the formation of simple sugars such as fructose and glucose in the fruit Similarly, the contents of volatile substances, fragrances and essential oils showed a tendency for growth during fruit maturation. A comparison of the initial and final stage of the observation showed an over 5-fold increase in these rates. An opposite tendency was observed in the case of changes in the contents of ash, resulting from the processes of natural mineralization. On the other hand no statistically significant differences were identified in water content in the fruit. Apples at the final stage of fruit set, and at harvest maturity contain similar amount of water, oscillating around $82 \%$. Because cells strive to achieve balance between osmotic pressure and emerging structural stresses the content of water may slightly change in course of ripening (Frankel et al., 2012).

Table 4 Results of analytical tests (mean \pm standard deviations) for the consecutive assessments of Elkat strawberry variety

\begin{tabular}{ccccc}
\hline Date of test & Total solids, $\%$ & $\begin{array}{c}\text { Content of } \\
\text { water, } \%\end{array}$ & $\begin{array}{c}\text { Content of ash, } \\
\%\end{array}$ & $\begin{array}{c}\text { Content of } \\
\text { volatile } \\
\text { substances, } \%\end{array}$ \\
\hline 20.05 .2014 & $5.87^{\mathrm{a}} \pm 0.2$ & $92.71^{\mathrm{a}} \pm 0.05$ & $0.32^{\mathrm{a}} \pm 0.01$ & $1.36^{\mathrm{a}} \pm 0.08$ \\
\hline 10.06 .2014 & $6.60^{\mathrm{b}} \pm 0.07$ & $92.66^{\mathrm{a}} \pm 0.02$ & $0.28^{\mathrm{a}} \pm 0.03$ & $1.64^{\mathrm{b}} \pm 0.03$ \\
\hline 30.06 .2014 & $7.30^{\mathrm{c}} \pm 0.04$ & $92.31^{\mathrm{a}} \pm 0.15$ & $0.29^{\mathrm{a}} \pm 0.01$ & $1.95^{\mathrm{c}} \pm 0.03$ \\
\hline Legend: the same letters (for each parameter) show there are no statistically significant differences at $p=0.05$
\end{tabular}

Statistically significant changes were observed in the value of total solids in Elkat variety of strawberries. During the maturation process the value of this parameter increased nominally by approx. $1.5 \%$. Pineli et al. (2011) demonstrated that the change of green into red colour during vegetation of strawberries was a result of $2 \%$ increase in soluble solids. Similarly, the contents of volatile substances, fragrances and essential oils showed a tendency for growth during fruit maturation and reached the nominal value of $0.5 \%$. On the other hand no statistically significant differences were identified in the contents of water and ash in the fruit. These parameters amounted to approx. $92 \%$ and $0.3 \%$, respectively. According to Frankel and Hartman (2012) contents of water in strawberry and tomato prior to their harvesting (green fruit) changed only by $0.02 \%$ by the time the fruit turned red. 
Table 5 Results of analytical tests (mean \pm standard deviations) for the consecutive assessments of Bonaparte tomato variety

\begin{tabular}{lcccc}
\hline Date of test & Total solids, $\%$ & $\begin{array}{c}\text { Content of } \\
\text { water, } \%\end{array}$ & $\begin{array}{c}\text { Content of ash, } \\
\%\end{array}$ & $\begin{array}{c}\text { Content of } \\
\text { volatile } \\
\text { substances, } \%\end{array}$ \\
\hline 20.05 .2014 & $4.53^{\mathrm{a}} \pm 0.04$ & $93.12^{\mathrm{a}} \pm 0.15$ & $0.43^{\mathrm{a}} \pm 0.01$ & $0.88^{\mathrm{a}} \pm 0.06$ \\
\hline 10.06 .2014 & $4.83^{\mathrm{b}} \pm 0.04$ & $94.27^{\mathrm{a}} \pm 0.05$ & $0.40^{\mathrm{a}} \pm 0.01$ & $0.92^{\mathrm{b}} \pm 0.07$ \\
\hline 30.06 .2014 & $5.3^{\mathrm{c}} \pm 0.04$ & $94.47^{\mathrm{a}} \pm 0.06$ & $0.45^{\mathrm{a}} \pm 0.01$ & $0.96^{\mathrm{c}} \pm 0.02$ \\
\hline Legend: the same letters (for each parameter) show there
\end{tabular}

Legend: the same letters (for each parameter) show there are no statistically significant differences at $p=0.05$

Statistically significant changes were observed in the value of total solids in Bonaparte variety of tomatoes. During the maturation process the value of this parameter nominally increased to over $1 \%$. According to Toor et al. (2006), the contents of total solids in tomatoes depended mainly on cultivars. During the ripening process the amount of soluble substances increases nearly two-fold During growth of tomato fruit there is also an increased proportion of sugars (Dominguez et al 2012). Similarly, the contents of volatile substances, fragrances and essential oils showed a tendency for growth during fruit maturation, to finally reach the threshold value of $1 \%$. On the other hand no statistically significant differences were identified in the contents of water and ash in the fruit. During the final stage these parameters reached the values of 94.5\% and $0.45 \%$ respectively. Musse et al. (2008) reported that in the case of tomatoes changes in water content during the process of ripening was not statistically significant. These authors noticed that during vegetation, after eighteen days, before harvest, the content of moisture was at the level of $95.6 \%$ and two days before potential harvest it decreased to $95.0 \%$.

The following results (Figure 1 and 2) show the trend in the changes of the calorific value of dry matter, which mainly consists in simple sugars, and starch, pectins, organic acids and pigments, i.e. these ingredients which, after the total moisture content has been evaporated, enter the matrix and produce calorific response during the test.

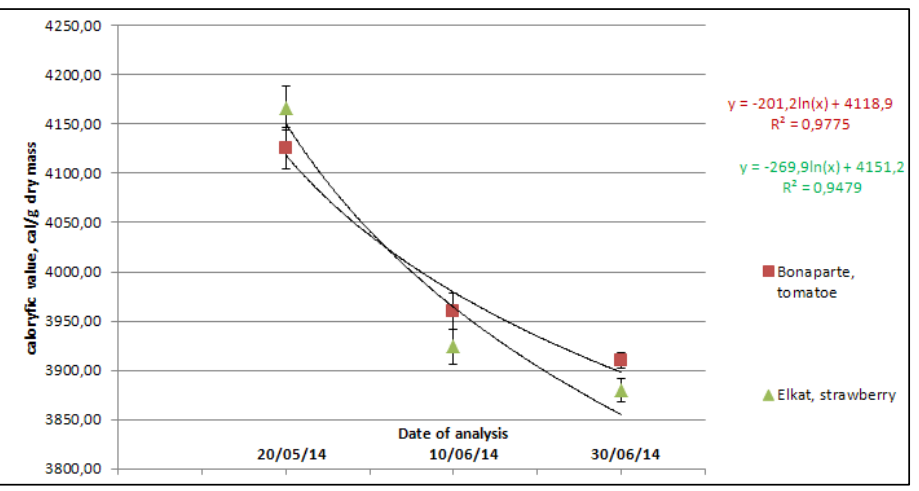

Figure 1 Changes in the calorific value of tomatoes and strawberries dry matter during consecutive analyses (for dates of analysis see Table 2).

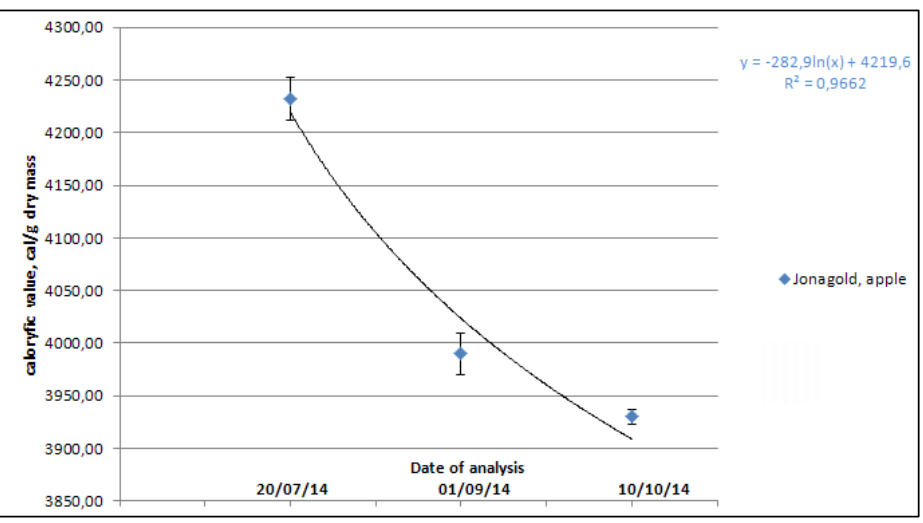

Figure 2 Changes in the calorific value of apples dry matter during consecutive analyses (for dates of analysis see Table 2).

It was observed during the consecutive analytic trials that the calorific value of the fruit dry matter tended to decrease from over $4100 \mathrm{cal} / \mathrm{g}$ for each fruit to the level of $3900 \mathrm{cal} / \mathrm{g}$. Given the constant rates for moisture content in the specific fruits, shown in Tables 3-5, we can postulate there is a general tendency showing changes in the calorific value in fruit, calculated for the fresh matter. The calorific value decreased so visibly that it can be concluded the differences between the specific dates of assessment were statistically significant, at the significance level of 0.95 . The flattening trend lines show that the decrease in the calorific value is gradually inhibited in the examined fruit; this might in fact indicate the optimum harvest maturity in these fruits.
As it was already mentioned, the changes in the fruit calorific value are mainly impacted by the caloric response of such components of the dry matter as simple sugars, and starch, fruit acids, pectins, and pigments. Each of these components contributes its unique energy value, which is characteristic for each group of components (Tabel 6). The highest calorific value is a characteristic of fats, found in fruits in trace amounts only; the prevailing components are starch (in immature fruits) with calorific value of approx. $4200 \mathrm{cal} / \mathrm{g}$, and monosaccharides (at the later stage) with the calorific value of approx. $3950 \mathrm{cal} / \mathrm{g}$.

Table 6 Calorific value of the main components of fruit dry matter (Merrill $e t$ al., 1973)

\begin{tabular}{lc}
\hline Nutrient & Calorific value, cal/g \\
\hline Starch & 4200 \\
\hline Monosaccharides (fructose, glucose) & 3950 \\
\hline Pectins & 5890 \\
\hline Proteins & 5000 \\
\hline Fats & 9000 \\
\hline Organic acids & 4200 \\
\hline Pigments & 4200 \\
\hline
\end{tabular}

Moreover, the dominant components of fruit dry matter include sugars (in the examined fruits sugars account for $92-98 \%$ of the dry matter), and at the initial stage, when the fruit is immature - starch, which later during the process of ripening is transformed into simple sugars. Calorific value of starch is higher than that of simple sugars (Table 6), therefore the present findings simply reflect the changes occurring in the fruits. More calorific starch is transformed into less calorific monosaccharides, and as a result the calorific value of the fruit decreases. Hence, it is possible to identify the moment when the calorific value of fruit dry matter is approx. $3900 \mathrm{cal} / \mathrm{g}$, i.e. when starch has mostly broken down into glucose (possibly to be further transformed into fructose), which might be the way to determine the optimum timing for fruit harvest. In the case of apples the calorific value should be slightly higher than in tomatoes or strawberries, due to the fact that the latter are harvested at the time they are ready to for consumption. Unlike these, apples of Jonagold variety and other fruit of this type achieve ripeness for consumption during a prolonged process of storage.

Given the above, an application was filed to patent „The method of determining harvest maturity in fruit", which was approved by the Patent Office, and marked with symbol P.406446.

\section{CONCLUSION}

Authors created new method and new tool useful for determination of harvest date or maturity stage It seems important to create a table of calorific values for fruits in their harvest maturity time for each of their species and varieties

Acknowledgments: The study was carried out in the framework of the research project: „Innovation-oriented University of Rzeszów” No. 2/IUR/KI/2012 entitled: "Advanced calorimetric method of determining harvest maturity in fruits".

\section{REFERENCES}

Błaszczyk, J. (2006). Wpływ terminu zbioru na właściwości przechowalnicze jabłek odmiany 'Topaz' [Impact of harvest timing on storage properties of Topaz variety apples]. Zeszyty naukowe instytutu sadownictwa i kwiaciarstwa. 14, 8793.

Domagała, D., Guz, T. (2007). Zastosowanie wybranych metod analizy obrazu podczas obserwacji rozpadu skrobi w jabłkach [Application of selected methods of image analysis during observation of starch decomposition in apples] Inżynieria Rolnicza, 5 (93), 81-87.

Dominguez, E., Fernaindez, F., Carlos, J., Hernaindez, L., Perez, J. (2012). Tomato fruit continues growing while ripening, affecting cuticle properties and cracking. Physol. Plant., 146, 473-486. http://dx.doi.org/10.1111/j.13993054.2012.01647.x

Frankel, CH., Hartman, T.G. (2012). Decrease in fruit moisture content heralds and might launch the onset of ripening processes. Growing Systems. J Food Sci,. 77(10), 365-376. http://dx.doi.org/10.1111/j.1750-3841.2012.02910.x

Kang, S.P., East, A.R., Trujillo F.J. (2008). Colour vision system evaluation of bicolour fruit. Postharvest Biology and Technology, 49. 152-155. http://dx.doi.org/10.1016/j.postharvbio.2007.12.011 
Łysiak, G. (1998). Wstępna ocena pięciu metod określania terminu dojrzałości zbiorczej jabłek [Initial assessment of five methods of determining harvest maturity in apples]. XXXVII Polish Conferences, Skierniewice, 296-299

Merrill, A.L., Watt, B.K. (1973). Energy value of foods. Agriculture Handbook,

74,3 .

Mizrach,, Flitzanov, U., Akerman, M., Zauberman, G. (2000). Monitoring avocado softening in low temperature storage using ultrasonic measurements Computers and Electronics in Agriculture, 26, 199-207. http://dx.doi.org/10.1016/s0168-1699(00)00072-7

Musse, M., Quellec, S., Lambert, M., Devaux, M., Lahaye, M., Mariette, F. (2008). Monitoring the postharvest ripening of tomato fruit using quantitative MRI and NMR relaxometry. Post. Biol. Technol., 53, 22-35 http://dx.doi.org/10.1016/j.postharvbio.2009.02.004

P.406446. Zaguła, G., Puchalski, Cz., Czernicka, M. (2013). Sposób określania dojrzałości zbiorczej owoców [Method of determining harvest maturity in fruit]. Biuletyn Urzędu patentowego RP.

Peirs, A., Scheerlinck, N., Perez, A. B., Jancsók, P., Nicolai, B. M. (2002)

Uncertainty analysis and modelling the starch index during apple fruit maturation. Postharvest Biology and Technology, 26, 199-207. http://dx.doi.org/10.1016/s0925-5214(02)00038-8

Pieniążek, S.A. (1995). Sadownictwo [Fruit farming]. Warszawa, ISBN 83-0901622-0

Pineli, L.P., Moretti, C.L., Santos, M.S., Campos, A.B., Brasileiro, A.V., Cordova, A.C., Chiarello, M.D. (2011). Antioxidants and other chemical and physical characteristics of two strawberry cultivars at different ripeness stages. $J$ Food Comp Analysis, 24, 11-16. http://dx.doi.org/10.1016/j.jfca.2010.05.004

PN-90/A-75101: (2003). Fruit and vegetable. Determination of dry weight by weight (Polish standard)

PN-C-04708-3 : (1997). Food colors. Determination of volatiles (Polish standard).

PN-EN 1135: (2002). Fruit and vegetable juices. Determination of ash content (Polish standard)

PN-EN 14918: (2010). Solid biofuels - Determination of calorific value (Polish standard).

Puchalski, C. (2001). Metodyczne aspekty badania tarcia i jędrności jabłek pod kątem ich jakości [Methodology aspects of assessing friction and firmness in apples from the point of view of their quality]. Rozprawy Akademii Rolniczej im. H. Koltataja w Krakowie, 275, 53-54.

Steinmetz, V., Roger, J.M., Molto, E., Blasco, J. (1999). On-line fusion of colour camera and spectrophotometer for sugar content prediction of apples. J. Agric Engng Res., 73, 142-155. http://dx.doi.org/10.1006/jaer.1999.0407

Tomala, K. (1995). Prognozowanie zdolności przechowalniczej i określenie terminu zbioru jabłek [Forecasting storage capacity and determining harvest maturity in apples].

Tomala, K. (2002). Dlaczego termin zbioru owoców jest taki ważny [Why is harvest timing so important] Owoce, warzywa, kwiaty. 16, 24-26.

Toor, R.K., Savage, G.P., Lister, P.D. (2006). Seasonal variations in the antioxidant composition of greenhouse grown tomatoes. Food Comp. Anal., 9, 110. XXXVII Ogólnopolska Naukowa Konferencja Sadownicza [37th Polish Conference on Fruit Growing] . Skierniewice, Wydawnictwo ISiK, 296-299. http://dx.doi.org/10.1016/j.jfca.2004.11.008

Zaguła, G., Puchalski, CZ. (2013). Zmiany glukozowo - fruktozowe w jabłkach poddanych oddziaływaniu stałych i wolnozmiennych pól magnetycznych [Changes in glucose and fructose contents of apples exposed to constant and slowly changing magnetic fields]. Żywność. Nauka. Technologia. Jakość, 2 (87), 162 - 172. http://dx.doi.org/10.15193/zntj/2013/87/162-172 